University of Nebraska - Lincoln

DigitalCommons@University of Nebraska - Lincoln

$2-1942$

\title{
English in Wartime: A Symposium by College Teachers
}

Louise Pound

Karl Young

P. G. Perrin

Charles Child Walcutt

R. S. Crane

See next page for additional authors

Follow this and additional works at: https://digitalcommons.unl.edu/englishfacpubs

Part of the Comparative Literature Commons, English Language and Literature Commons, Modern Literature Commons, and the Reading and Language Commons

This Article is brought to you for free and open access by the English, Department of at DigitalCommons@University of Nebraska - Lincoln. It has been accepted for inclusion in Faculty Publications -Department of English by an authorized administrator of DigitalCommons@University of Nebraska - Lincoln. 


\section{Authors}

Louise Pound, Karl Young, P. G. Perrin, Charles Child Walcutt, R. S. Crane, Louise M. Rosenblatt, Warner G. Rice, George R. Coffman, and Oscar James Campbell 


\section{ENGLISH IN WARTIME}

\section{A SYMPOSIUM BY COLLEGE TEACHERS}

After the declaration of war upon us by the Axis nations, it seemed to the editors of College English that the members of the College Section should, as soon as possible, co-operate in determining how best to fulfil our special responsibility throughout World War II. As a first step, we invited twenty-five teachers of English in colleges and universities to suggest how we should meet this professional emergency.

The Planning Commission of the N.C.T.E., at their meeting in Chicago during the Christmas holidays, and the College Section, at their meeting in Indianapolis with the M.L.A., considered general and basic wartime policies for the National Council. The result of these deliberations will be presented in the March College English.

To assemble a preliminary survey of opinion on the teaching of English in World War II, we had to act quickly in order to meet the deadline for the February issue. Nine letters from college men and women came back in time to be included in the symposium. The weakness of the small number, however, is overcome by the strength of the unified and obviously representative character of the responses. Teachers of English believe in the permanent value of the work they are doing. In peace or in war the discipline of the humanities is a way to decency in human relations. Those who have written for the symposium agree that our time of emergency requires of us, as teachers of English, a more vigorous concentration than ever upon clear expression and broad, permanently vital reading.

We will need to make curriculum 'changes, and individually we will perform special wartime duties; but the initial message from outstanding college teachers is that we must do the job for which we are trained: help others to realize the power which emanates from great literature to live humanely in the midst of conflict.

I

No doubt there will have to be curtailment of classroom courses in English as well as of other courses in the curriculums of our schools and colleges; and no doubt here and there expansions may be needed. Both may be salutary. Careful thought should be given them, and it will be. There was never before a time when patient scrutiny and investigation so 
characterized the efforts of educators as they do today. There was never before so much exact experimentation to determine what is wisest. Leaders in education have brought improvement in the past, in their pressure for progress, even in their incessant shifts of emphasis and their shifting catchwords, which are launched, worked hard, then replaced.

I hope that in the time ahead the study of literature for literature's sake may still have place; that literature may still be looked on as a record of human thought and feeling and a storehouse of the past. From the reading of the monuments of many periods, and only from this, can the types, laws, history, and changing character of human thought be illustrated. The tendency toward emphasizing the merely contemporary in the classrooms of wartime days needs no reinforcement. Its advocates are many and vigorous. There is need, however, of sympathetic understanding of man's record in the past, if only for the steadying effect this may have on our understanding of the present; and here there is real need for reinforcement.

In brief, while we emphasize the practical and contemporary as we should, and curtail excursions into the minutiae of literary history, into text problems and problems of interpretation, and into overspecialization, I hope that we do not sacrifice the ideals of culture and a liberal education.

\section{UNIVERSITY OF NEBRASKA}

Louise Pound

II

I surmise that the momentary shift in our teaching of our subject ought to be slight, though it will be important. We shall, of course, give a fresh emphasis to democracy and Americanism; but probably the shift will not be momentous.

What some of us will do, no doubt, is to teach other subjects, citizenship, for example, as in the last war. We may be asked to give instruction in military correspondence, etc., and I'm ready to serve; but that will have little to do with our proper academic responsibility, and I myself should not be inclined to boast about any such service as a departmental achievement.

YALE UNIVERSITY

KARL YOUNG

\section{III}

December I 7, I94I. The first thing for us to realize as college teachers of English is that we are not training soldiers but that now as always our contribution is to our students as future men and women. Even the "great tradition" and the "democratic way" they will learn better by 
observation and practice than by professorial or literary indoctrination. We must do all in our power to make our work count to them as individuals and to make it real enough so that it can help college work compete with the urgent appeal of practical affairs. We must act so as to show them that their lives and ours will continue, altered somewhat but not wrecked.

We shall have to abandon some of our favorite specialties, if they are remote from the natural interests of a normal but unspecialized person. We shall have to abandon, if we have had it, the goal of making undergraduates carbon copies of "Ph.D.'s in English." To be less occupied with the minutiae of literary history will not mean abandoning of "standards." It will give us more time to devote to meaningful literature, to the intelligent reading of the best from the past and the better of the present, of literature that can in some respects be a part of experience. In composition we have more reason than ever before for trying to see over our chins, to give up the petty refinements of literary English, to become positive instead of negative, to encourage better writing of actual, purposeful, modern sorts. This does not mean business letters or Army paper work but just clear-cut expression of ordinary ideas in a modern idiom and in forms actually written and read today. We can sometimes help students clarify their attitudes by encouraging them to reflect enough on their own situation to be able to discuss it in words rather than leave it in vague, unresolved moods.

In short, we now have good reason for sloughing off some matters that we have become a little suspicious of and for concentrating on what should constitute our essential work in peace as well as in war. We can no longer afford to be precious or snobbish or highbrow but rather must illustrate in our work the realism that students are being forced to accept in their own lives. This does not mean surrender of standards or ideals but a fresh selection and emphasis in accordance with a new and human perspective.

\section{Colgate University}

P. G. PERRIN

\section{IV}

I heartily agree that English teachers should determine what changes are to be made in English teaching rather than bend to the pressures of hysterical or selfish groups. But we English teachers have a greater obligation than merely to defend our position. Our position is creative. We stand for the liberal tradition of Western civilization, and we are, by virtue of being English teachers, devoted to interpreting and disseminating its best values. In a world which has abandoned itself to force, our obligation increases as these values are threatened. 
During the last war many teachers were guilty of forgetting their humane pursuits in an orgy of hatred which they vented in persecuting imagined enemies. How far we have advanced from such inhumanity is indicated by a report of a speech in the morning paper, urging men not to forget that "there are people with culture, art and kindness in these [enemy] nations, people just like we are, and they have played no part in bringing on war." When a journalist achieves such sanity and tolerance, the English teacher must rise even higher. He must, I believe, first and foremost show that he embodies the values he teaches. While hatred and hysteria mount, he must maintain in word and deed his awareness that war is never an end in itself but at best only a lamentable means which has been forced upon us. The good that may follow this upheaval will not come about by any miracle. The will for a just peace and a better order will not suddenly appear: It will exist only if it has been preserved and nurtured through the war. This is our task.

Applied to the curriculum - a small consideration when compared with our outlooks and attitudes-this means that we must not teach hatred, jingoism, or propaganda. We must insist that no emergency is so great as to justify abandoning the larger truth. The greatest emergency, on the contrary, is the present threat to liberality and intellectual freedom. Our task is to preserve and champion the only values that can save the world after the present fever has been purged.

With such a purpose in mind, some valuable changes in curriculum might be attempted. Literary as well as composition courses might dwell upon the humane tradition, for by studying it we shall arouse enthusiasm for it and thus keep our students' minds on the long view and the larger issues. They will have more than enough stimulation to hate. We must compete, with a vital, sincere, and enthusiastic affirmation of the worth of the individual. Let us $b e$ wise, humane, creative, and let us teach what we are.

UNIVERSITY OF OKLAHOMA

Charles Child Walcutt

\section{$\mathrm{V}$}

It would seem to me that if our present curriculum in English is thoroughly sound from the point of view of the long-run intellectual and literary good of our students, no changes should be made in it as a consequence of the new war, except possibly in such details as the selection of particular texts for discussion and the emphasis with which we present them. On the other hand, if our program appears to us now not to have 
been altogether sound, I think we should take every advantage of the present crisis to re-examine what we have been doing in terms of fundamental educational and cultural ends. I suspect that some changes may be forced upon us by circumstances beyond our control, but I very much hope that we will not be rushed into making hasty adaptations of our subject to the apparent needs or emotions of the moment. We have done altogether too much of that in the past generation, and I am sure that much of the confusion of thinking and values which preceded the beginning of this war can be directly traced to the propensity of not merely ourselves but nearly all educators to concentrate on expedients and devices suggested by passing situations rather than to discover and hold fast to the fundamentals of our discipline.

University of Chicago

R. S. CRANE

\section{VI}

Neither we nor our students should function in the classroom other than as complete human beings. Hence it should be inevitable that the teaching of English, like the rest of our life, should be profoundly affected by our entrance into the war. Now less than ever before should we be guilty of ignoring that these young people bring to the work of the college course preoccupations, perplexities, and hopes growing out of the life that impinges so sharply upon them. We should betray our trust if we did not seek to make the study of English language and literature a means for clarifying and ordering their understanding of themselves and of the wartorn world about them.

But this does not mean that we should be content to make hasty changes in our practices and procedures, designed to indicate a superficial recognition of the war situation. Special courses may undoubtedly be introduced to meet specific needs and curiosities. The important changes that I envisage would not, however, be merely "for the duration." And, above all, they do not imply the use of our English classes to whip up feeling in the light only of the present military conflict. We shall have to stand firm, no matter how shrilly the zealous but misguided demand that we be superficial, unscholarly, unscientific. To seek to impose upon our students. unthinking emotional acceptance of even the worthiest slogans would be in the end disservice to our cause.

The changes that I hope for, though precipitated by the war, will be equally valid for the peace. Teachers of English will be challenged by the present crisis to scrutinize their work to determine how fully it serves the 
end of preserving the humane system of values which is our most precious heritage through carrying it alive into the hearts of those they teach. They will succeed only if they strive to bring into the college classroom a continuing responsiveness to the nature and concerns of the human beings who are their students. The experience of literature will thus become an important means of developing the awareness of alternatives, the sense of human dignity, and the balanced judgment required of those who are to be the "carriers" of the democratic tradition.

We shall, I hope, accept frankly the responsibility of helping our students to approach the literature of the past and present with eagerness and with increasing capacity to discriminate between what is anachronistic and destructive and what is worthy of preserving. Together with our students we can make the study of our language and literature a source of strength, a means for forging a passionate yet reasoned belief in the values we are defending. This will enable us to contribute not only to winning the war but also to winning the peace out of which can come a fruition of our democratic ideal.

BRookryn COLLEge

Loutse M. RosenblatT

\section{VII}

I feel that our teaching of English is likely to be changed as a result of our entrance into World War II, but it seems to me that it will be most unfortunate if it is hastily modified. On the whole, it is my view that the changes which come should be changes that are necessary whether we have war or not and that the strengths of our English teaching - and indeed of all teaching in the humanities-must be the same whether or not armed hostilities are going on.

In these times, above all others, we need to reassert the value of the humanities in making people intelligent, understanding, and humane. The instruction which we give, both in composition and in literature, must encourage clarity of thought, accuracy of expression, and the development of the powers of the imagination through which we participate in the experiences of others. It seems perfectly true that we shall have to introduce some new technical courses in order to develop quickly the ability of speakers of other languages to handle English, and it is certain that we must emphasize afresh the value of our cultural tradition. Neither of these calls, however, for a revolution in our way of doing things.

UNIVERSITY OF MICHIGAN

WARNER G. RICE 


\section{VIII}

During the first World War, I expressed a credo for those times. I searched in my files. Here it is as it appeared in the Nation (New York), May 4, IgI 8 , page 528 :

\section{ENDURING VALUES IN LITERATURE}

\section{To the EDIToR of The Nation:}

In our colleges and universities, in connection with the present urge towards nationalism and internationalism, we should teach the literature of England and America as reflecting the social, religious, and political ideals of our people. But we should not do this to the neglect of the permanent function of literature.

There is a sense of enduring values in great literature that is timelessbeyond the present ghastly world tragedy. The soldier who wrote from the trenches that it was the recalling of bits of poetry he had memorized years before which saved him from insanity, suggests in part that sense of enduring values. So also does the man who sent back from the fighting line: "On such a day as this, one wishes to read well-expressed words which deal with eternal things."

We should realize that if this country is to avoid the narrow vocationalism of Germany, among other essentials, teachers of literature must co-ordinate with the necessary work along restricted professional or vocational lines the cultural qualities of great literature. We should reach through literature the best spirit of national patriotism and the coming internationalism. "Literature exists to please - to lighten the burden of men's lives; to make them for a short while forget their sorrows and their sins, their silenced hearths, their disappointed hopes, their grim futures."

Let us give to those of our colleges and universities who may still pay the supreme sacrifice in this colossal tragedy a sense of the enduring value of culture and the humanities-life's imponderables. We should be interpreters of literature to students keenly responsive to the moral values of life. We should let them realize those values through the integrity of such artists as Chaucer, Shakespeare, Milton, Browning, and Hardy.

In these times it is still my creed for teachers of English and American literature.

UniverstTy OF NORTH CAROLINA

George R. Coffman

\section{IX}

Our first sharp "No" to the question, "Can the teaching of English remain unchanged by our entrance into World War II?" must not lead us headlong into the office of a ministry of propaganda. We must not forget that we are educating young people not for the next three years alone but 
for their entire lives. If students must be quickly conditioned for the war years, let the social scientists undertake that job. Our subject must influence personality on deeper and more permanent levels. One of our duties is to keep our students, now more than ever before, in the great stream of humane Christian culture which comes from the past. In times of turmoil like these young people need desperately to grasp firmly ethical truths that have been tested by time. To attempt to prepare them for a completely unknown future or even to fit them supinely into a war-torn world is to be faithless to our subject.

Never in the history of the world was provincialism in time and place more dangerous. To study only contemporary books now is to offer no release from the present confusion. To study only or chiefly American literature is to encourage the state of mind that produced purblind isolationism.

Let us remember that the deepest convictions and the most salutary emotional attitudes are not won by direct attack. Macbeth, properly taught, can produce a better understanding of the character of Hitler's immoral power politics and its destructive effect upon Germany than the ringing invectives of Winston Churchill. The ways of imagination and emotional analogy are the deepest currents of the human mind. In those subterranean channels the permanent impulses to action are formed and their direction determined.

In brief, let us not in a mad rush to be immediately practical forget the place of English in education. Let us not become street-corner orators or advertising agents for this or that aspect of defense. Our main effort must be, as always, to keep alive those generous individual and social impulses which make and preserve civilization. So let us keep on our academic shirts. Let us not pull them wildly off and toss them into the fire of the world-conflagration.

Columbia UnIVERSITy

Oscar James Campbell 